\title{
Nixtamalized maize supplementation with a sardine protein concentrate to improve the biological value of tortillas
}

\author{
Mardia López-Alarcón, ${ }^{1}$ Irene Montalvo-Velarde, ${ }^{2}$ Lilia Bernal-Gracida ${ }^{3}$ and María de Lourdes \\ Barbosa-Cortés ${ }^{1}$ \\ 'Instituto Mexicano del Seguro Social, Centro Médico Nacional Siglo XXI, Pediatrics Hospital; '2Universidad La Salle, Faculty of Chemistry;
} ${ }^{3}$ Universidad Nacional Autónoma de México, Faculty of Chemical Sciences, Department of Biochemistry, Ciudad de México, Mexico

\begin{abstract}
Introduction: Most part of the rural population in Mexico obtains almost half its energy from corn tortilla, and its sources of protein are mainly of vegetal origin. Objective: To obtain a concentrate of sardine protein (SP) to supplement corn flour, and to identify which concentration provides corn tortillas with a better biological value, without modifying its physical and sensorial characteristics. Method: Obtainment of the SP concentrate, preparation of tortillas with corn flour and different SP concentrations, assessment of tortillas physical and sensorial characteristics by untrained panelists, assessment of biological quality in a murine model (growth and protein efficiency ratio [PER]). Parametric statistics was used. Results: $A$ protein concentrate of $70.48 \mathrm{~g} / 100 \mathrm{~g}$ was obtained. Smoothness, blistering, foldability and quality of the tortillas prepared with mixtures containing 0.63-3.75\% of SP were comparable to those of tortillas prepared with non-supplemented flour. The growth of rats fed supplemented tortillas was superior; the difference was significant with $\geq 3.75 \%$ concentrations $(p<0.05)$. The PER of tortillas with $3.75 \%$ of SP was 2.41, which was comparable to that of the reference protein (casein). Conclusion: SP-supplemented corn flour at a 96.25:3.75\% ratio improves the biological value of tortillas without modifying their physical and sensorial characteristics.
\end{abstract}

KEY WORDS: Nixtamalized maize. Sardine. Protein concentrate. Corn tortillas.

\section{Introduction}

Even when overweight and obesity are top priority health problems in Mexico, National Nutrition Surveys in Mexico show that children undernutrition remains an important problem, especially in rural areas..$^{1-4}$ For example, an analysis of nation-wide stunting rates shows an important descending trend but, in rural areas, prevalence remains high, with a rate higher than $20 \% .{ }^{4}$ In fact, rural areas from the south of the country maintain a prevalence of low height that is 13.9 percentage points higher than national average (27.5 versus $13.6 \%$ ). ${ }^{4}$ As for diet, the most recent National Nutrition Survey reports that, although in the country there is an excess in energy consumption deriving from dairy and non-dairy sweetened foods, less than $50 \%$ of the rural population consumes the recommended foods that provide quality proteins such as eggs, non-processed meat and dairy products, and only around $60 \%$ consume the recommended energy intake and with high fiber content. These dietary deficits are even more serious in school-age children than in adolescents. ${ }^{5}$

The main nutritional influence on growth in developing countries is protein and energy consumption. ${ }^{6}$ In addition, protein requirements increase to the extent energy requirements are not met. ${ }^{7,8}$ On the other hand, in developing countries, main protein sources are often vegetables and grains, which provide low biological value proteins. ${ }^{8}$ In Mexico, particularly in rural areas, most part of the population acquires at least half of its energy from corn (maize) tortilla, and protein sources are mainly of vegetable origin, which
Date of reception: 17-03-2017

Date of acceptance: 09-11-2017

DOI://dx.doi.org/10.24875/GMM.M18000150
Gac Med Mex. 2018;154:267-273

Contents available at PubMed www.gacetamedicademexico.com 
makes it to be of low quality. ${ }^{9}$ It is important taking into account that corn protein has low lysine and tryptophan concentrations, in addition to an imbalance in the leucine and isoleucine proportion, which are factors that interfere with linear growth. ${ }^{10,11}$ Analyzing this as a whole, it is probable that in developing countries' populations, dietary protein use is inefficient owing to an energy deficit, and even if protein intake is adequate, the consumed protein is of low biological value and to a large extent growth-limiting for originating almost entirely from corn.

Previous, very old studies carried out in children, ${ }^{12,13}$ adults $^{14}$ and experimental animals ${ }^{15}$ showed that nixtamalized maize nutritional value can be enhanced by simultaneously adding the 3 limiting amino acids: lysine, tryptophan and isoleucine, which owing to its high cost is hardly feasible at the population level. In animal models, improvement of maize tortilla quality has also been demonstrated when supplemented with flour of legumes such as beans, soy, chickpeas, fava beans and lentils, but its use in humans has been insufficient to improve the population nutritional status. ${ }^{16,17}$ One study carried out in Mexico in human subjects, where tortillas were prepared with a blend of corn and soy flour, reported improvement in tortillas biological value, but no effect was demonstrated in children nutritional status. ${ }^{18}$

Supplementation with high biological value protein extract, such as that obtained from animal sources, in order to improve corn tortilla quality, has already been attempted..$^{19-21}$ Supplementation with fish flour has already been successfully carried out for animal feed, but its use in humans has not been accepted, mainly because grinded fish has been used (rather than protein extract), and the odor is therefore very strong and the tortilla characteristics are not acceptable for human consumption. ${ }^{20,21}$ For example, in 1957, whole yellow corn protein efficiency ratio (PER) was reported to improve from 0.61 to 1.34 , and growth in rats was increased from 21.5 to $71.1 \mathrm{~g}$, when a mixture of grinded fish was added in order to obtain a diet with comparable protein amounts. ${ }^{20}$ In humans, one study carried out with complementary diets for infants based on rice or corn, supplemented with different sources of protein such as beans, sardine, or both, demonstrated that amino acid scores, digestibility and efficiency rate were better in the diet with sardine mixtures..$^{21}$ It is important taking into account that, in both studies, ${ }^{20,21}$ supplementation was with mixtures of fish flour or whole fish and, in the study in humans, the effect on growth was not analyzed.
This way, evidence suggests that an adequate approach to the enhancement of corn nutritional quality is supplementation with high biological value protein, and fish protein appears to be a good option. In Mexico, sardines are cheap, abundant and contain high-quality protein; 22 therefore, it would be a good alternative. Although, ideally, incorporation of sardines to the diet would be more adequate, cultural and economic factors have prevented this food from being added to the Mexican diet, and it is therefore appropriate assessing the addition of a protein concentrate to corn flour in order to, eventually, improve children's growth.

However, it is essential assessing if addition of the protein concentrate to the corn flour does not modify tortilla physical and sensory characteristics, so that it is accepted for use in humans.

The purpose of this study was focused on obtaining a sardine protein (SP) concentrate to be added to corn flour at different proportions and identifying the blend that provides tortillas with acceptable characteristics for human consumption. In addition, to assess the biological value of tortillas prepared with the supplemented mixtures in an animal model by analyzing the tortillas PER and rats growth.

\section{Method}

Several experiments were carried out to obtain a sardine protein (SP) extract. Tortillas were prepared with blends of corn flour and different SP concentrations, and their physical and sensory characteristics were evaluated by a group of non-trained panelists. Subsequently, the tortillas biological quality was analyzed in an animal model by assessing growth curves in rats and PER.

Frozen sardines (Sardina pilchardus) were used, which were obtained from a local marked and stored at $-80{ }^{\circ} \mathrm{C}$ until being used. Once thawed, heads and intestines were removed from the sardines, and flesh and bones were grinded with a domestic grinder (KitchenAid, Hobart). The obtained blend was sieved through a mesh with 6-mm holes and then through another with 4-mm diameter holes. The obtained material was combined with water at a 1:4 ratio $(\mathrm{w} / \mathrm{V})$ and liquefied to obtain a homogeneous mixture. All this process was carried out at the Faculty of Chemical Sciences Biochemistry Laboratory of the National Autonomous University of Mexico.

The aqueous compound obtained was adjusted to an alkaline $\mathrm{pH}$ (12.0) using $\mathrm{NaOH} 2 \mathrm{~N}$. The stabilized mixture was centrifuged at $8000 \mathrm{~g}$ for 20 minutes at 
$4{ }^{\circ} \mathrm{C}$ in order to separate the soluble proteins. Neutral lipids remained on the upper part, and solid material, mainly connective tissue and bone, went to the bottom. This way, the half part of the mixture containing the solubilized proteins could be obtained. $\mathrm{pH}$ was adjusted to 5.5 to favor protein precipitation using $\mathrm{HCL}$ $2 \mathrm{~N}$ and protein was finally recovered after centrifugation at $8000 \mathrm{~g}$ for 20 minutes at $4{ }^{\circ} \mathrm{C}$ and drying with atomizer (air input temperature at $40^{\circ} \mathrm{C}$ and air output at $65^{\circ} \mathrm{C}$, at a rate of $30 \mathrm{~mL}$ minute $\left.{ }^{-1}\right)$. Protein content was determined with the Bradford method (1976), and concentration was calculated using bovine serum albumin as standard.

To make the tortillas, nixtamalized maize flour was used, and were prepared with non-supplemented flour and with flour supplemented with different SP concentrations. This way, dough blends with the following corn flour: SP were obtained: 92.5:7.5, 95.0:5.0, 96.25:3.75, 97.5:2.5, 98.75:1.25 and 99.37:0.63. The tortillas were made using a conventional press and were cooked by placing them on a hotplate for 2 minutes, approximately one minute for each side (Fig. 1).

To assess the tortillas physical and sensory characteristics, 20 untrained panelists who were not allergic to fish were invited, and subjective rating scales were used. Freshly made tortillas were evaluated using those prepared with non-supplemented corn flour as reference.

Flavor, taste, color, odor, softness (by applying pressure with the fingertips on the tortilla and observing the resistance to such pressure) and smoothness (absence of roughness on the tortilla surface) were rated, as well as puffing (formation of blisters at the last phase of cooking) and folding tests (by rolling up the tortilla and observing if the taco external part showed cracks) (Table 1). At the end, overall quality was assessed by asking if the tortilla was not acceptable, moderately acceptable or acceptable.

For the biological tests, only moderately and highly acceptable diets were considered.

For the assessment of the tortillas chemical characteristics, first the moisture content was determined according to the Association of Analytical Communities (AOAC). The moisture content was determined by drying the samples at $105^{\circ} \mathrm{C}$ in a conventional oven for 3 hours and calculating the percentage of weight difference between the moisturized sample and the dry sample. ${ }^{23}$ Then, the samples were dried at $60^{\circ} \mathrm{C}$ and grinded in a grain grinder and the flour was placed in hermetically sealed and labeled glass jars and kept in a fresh place for chemical analysis.
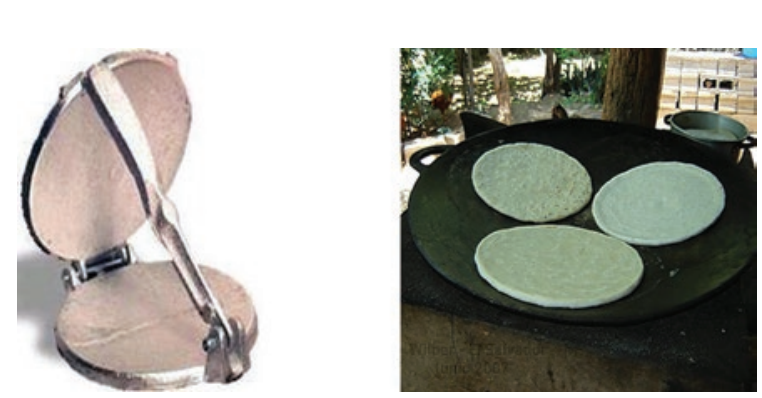

Figure 1. Press and hotplate used to make the tortillas.

Table 1. Scale for sardine protein-supplemented corn flour tortilla sensory evaluation

Softness ( )

0-1 = Moderately soft, resistant to pressure

2-3 = Soft, pressure with little difficulty

$4-5=$ Very soft, easily pressured

\section{Smoothness ( ) \\ $2=$ No roughness \\ $1=$ Roughness}

Folding ( )

2 = Flexible, rolls up, no cracks on taco exterior

$1=$ Moderately flexible, shows cracks but can be rolled up

$0=$ Brittle, it cracks so much that a taco cannot be formed

Puffing ( )

$2=$ Blisters on the entire surface

$1=$ Blisters, but not on $99 \%$ of surface

$0=$ No blisters

Flavor ( )

$3=$ Characteristic, same as corn tortilla

2 = Preferential, different but likable

$1=$ Acceptable, less likable than preferential

$0=$ Not acceptable, unpleasant

Color ( )

$3=$ Characteristic, same as corn tortilla

2 = Preferential, different but likable

$1=$ Acceptable, less likable than preferential

$0=$ Not acceptable, unpleasant

Odor ( )

$3=$ Characteristic, same as corn tortilla

2 = Preferential, different but likable

$1=$ Acceptable, less likable than preferential

$0=$ Not acceptable, unpleasant

Overall quality ( )

16-20 = Acceptable, excellent quality

11-15.99= Moderately acceptable, regular quality

$5-10.99=$ Not acceptable, bad quality

Protein content was analyzed with the Kjeldahl method, ash content, with incineration in a muffle furnace, raw lipid content, by extraction with solvents (Soxhlet), raw fiber, by acid and alkaline hydrolysis, and total carbohydrate content, by percentage difference with regard to the above determinations. The energy content was calculated based on the reference values $(4 \mathrm{kcal} / \mathrm{g}$ of protein, $9 \mathrm{kcal} / \mathrm{g}$ of fat and $4 \mathrm{kcal} / \mathrm{g}$ of carbohydrates. 
Table 2. Reference diet proposed by AOAC* for biological tests

\begin{tabular}{lc}
\hline Ingredient & $\mathbf{g} / \mathbf{1 0 0} \mathbf{g}$ of diet \\
\hline Protein & 10 \\
Vegetable oil & 8 \\
Mineral salts & 5 \\
Mixture of vitamins & 1 \\
Water & 5 \\
Cellulose & 1 \\
Carbohydrates: sucrose or dextrin & 70 \\
\hline *Energy: 392 kcal/100 Reference 23. &
\end{tabular}

*Energy: $392 \mathrm{kcal} / 100 \mathrm{~g}$. Reference 23.

\section{Biological tests}

PER was determined in the non-supplemented corn flour and in the blends selected in the sensory evaluation tests, using as comparator a casein diet, which is regarded as the protein quality reference.

Recently weaned (21 to 23 days from birth) Sprague-Dowley rats were used, grouped in 6-animal batches for each assessed diet. The animals were placed in individual cages and fed the problem and control diets for 21 days. During this time they were freely supplied water and food, with weight and ingested food being measured every 5 days in order for PER to be calculated using the following formula:

PER = weight gain (g)/protein consumption (g)

For the preparation of the isoproteic and isoenergetic diets, the formula proposed by AOAC was taken as a basis (Table 2).

\section{Statistical analysis}

The Minitab statistical program, version 17, was used for statistical analysis, with a one-way ANOVA being used for PER to be compared between the different diets and a two-factor one to assess growth in the different groups over time. For the comparison with the control-diet (non-supplemented maize flour), Dunnet post hoc test was used, and for the comparison between all diets, the Bonferroni test for simultaneous comparisons.

\section{Results}

In the experimental phase to obtain the protein concentrate, a compound containing $70.48 \mathrm{~g}$ of protein in $100 \mathrm{~g}$ of the product could be obtained (Table 3). Subsequently, tortillas were prepared with the proposed
Table 3. Proximate chemical analysis of the raw materials used for the preparation of supplemented tortillas

\begin{tabular}{lcc}
\hline Determination & Protein extract & \multicolumn{1}{c}{ Corn flour } \\
\hline Moisture & 9.42 & 52.77 \\
Protein & 70.48 & $\frac{4}{5} .12$ \\
Ash & 2.35 & 0.83 \\
Raw fat & 7.16 & 2.08 \\
Raw fiber & 0.0 & 1.74 \\
Carbohydrates & 10.59 & 38.46 \\
Kilocalories & 388.72 & $\frac{1}{6}$ \\
\hline
\end{tabular}

concentrations, which were observed to puff up and fold similarly as the tortillas prepared with non-supplemented corn flour from the 96.25:3.75 blend on (Fig. 2). The sensory tests analysis showed that softness, puffing and folding of the tortillas prepared with the lowest SP concentrations (3.75 to $0.63 \%$ ) were comparable to those of the tortillas made with non-supplemented corn four. As a consequence, overall quality of these tortillas was rated at as least regular. Although the sardine odor was perceptible at the 3.75 $\%$ SP concentration, the panelists considered it was not unpleasant (Table 5).

Proximate chemical composition was determined in the tortillas prepared with non-supplemented corn flour and in those made with corn flour with different SP concentrations added; protein addition was observed to be apparent from the lowest dose used on $(0.63 \%)$ (Table 4).

As regards the biological tests, the rats receiving casein or tortillas supplemented with 3.75 to $7.5 \%$ of SP grew more than those fed non-supplemented tortillas. The groups of animals that received the lowest protein concentrations also grew better than those fed on non-supplemented tortilla, although the difference did not reach statistical difference (Fig. 3).

Since the tortillas prepared with blends with high SP concentrations were inadequate in the sensory evaluation, PER was only obtained for the blends that were rated as regular and excellent. Table 5 shows that PER with the 96.25:3.75 blend was similar to that of casein, which was consistent with the results obtained in the rat growth analysis (Table 6).

\section{Discussion}

This study demonstrates that the quality of corn tortilla can be improved by supplementing it with 

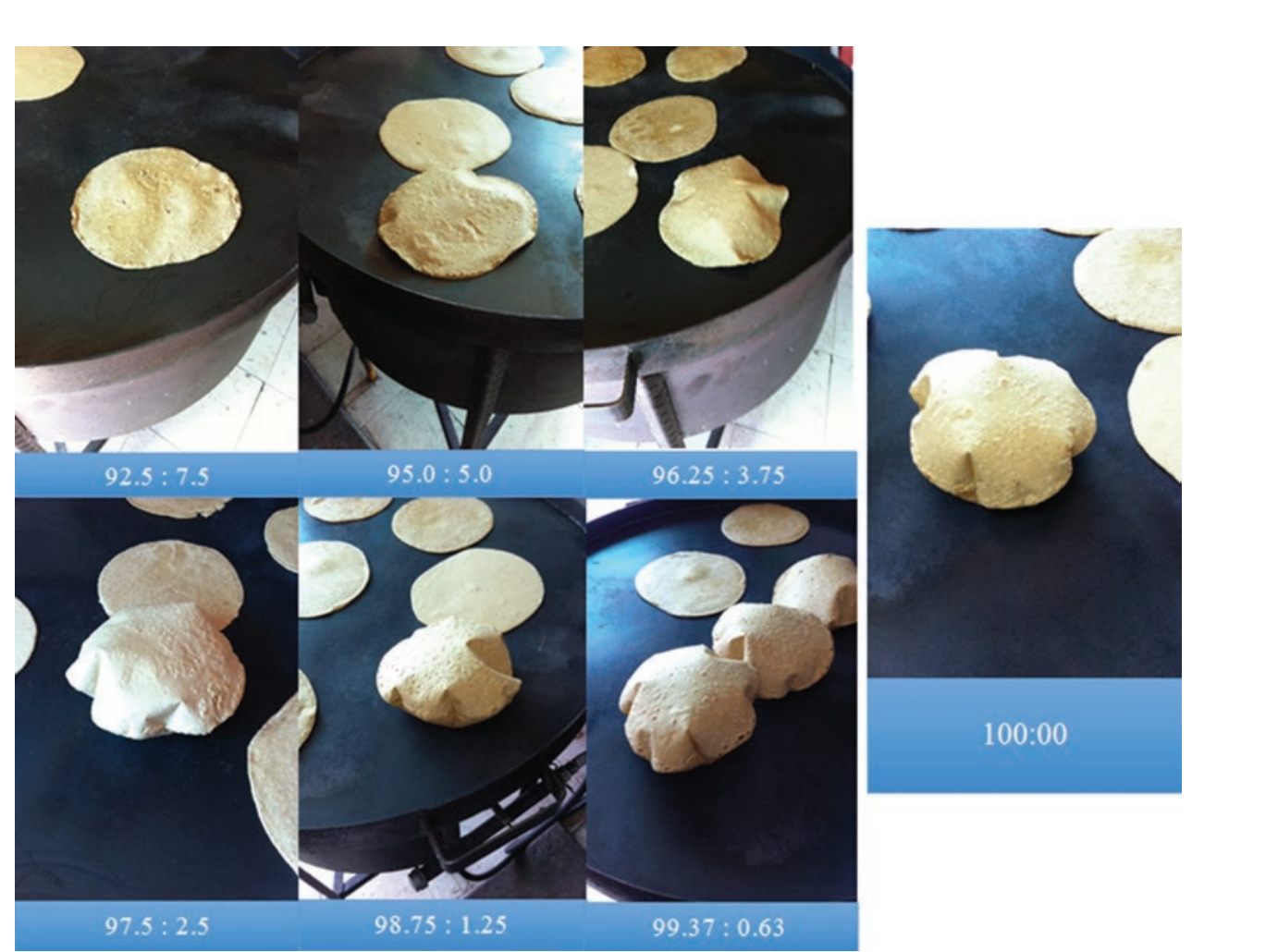

Figure 2. Puffing comparison between tortillas made with the different corn flour and sardine protein blends (corn flour: SP) and tortillas made with non-supplemented four.

Table 4. Proximate chemical analysis of tortillas prepared with different blends of corn flour and sardine protein*

\begin{tabular}{|c|c|c|c|c|c|c|c|c|}
\hline Parameter & $92.5: 7.5$ & $95.0: 5.0$ & $96.25: 3.75$ & $97.5: 2.5$ & $98.75: 1.25$ & $99.37: 0.63$ & 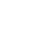 & 100 \\
\hline & \multicolumn{6}{|c|}{$\mathrm{g} / 100 \mathrm{~g}$, wet basis } & \multirow{4}{*}{\multicolumn{2}{|c|}{\begin{tabular}{l|l} 
& 46.89 \\
& 4.46 \\
& \\
& 1.04
\end{tabular}}} \\
\hline Moisture & 46.38 & 42.10 & 45.44 & 44.29 & 46.02 & 48.09 & & \\
\hline Protein & 10.41 & 9.09 & 7.79 & 6.85 & 5.29 & 5.16 & & \\
\hline Ash & 1.25 & 1.32 & 1.19 & 1.20 & 1.07 & 1.06 & & \\
\hline Raw fat & 1.38 & 1.26 & 1.27 & 1.17 & 1.17 & 0.94 & ○ & 1.14 \\
\hline Raw fiber & 1.15 & 1.79 & 2.05 & 1.75 & 2.02 & 2.11 & $\underset{J}{U}$ & 1.96 \\
\hline Carbohydrates & 39.43 & 44.44 & 42.26 & 44.74 & 44.43 & 42.64 & 은 & 44.51 \\
\hline Kcal & 211.8 & 225.5 & $\begin{array}{l}211.6 \\
\mathrm{~g} / 100 \mathrm{~g},\end{array}$ & 216.9 & 209.4 & 199.7 & 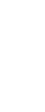 & 206.1 \\
\hline Protein & 19.42 & 15.70 & 14.28 & 12.29 & 9.80 & 9.95 & $\begin{array}{l}£ \\
\subseteq\end{array}$ & 8.40 \\
\hline Ash & 2.34 & 2.28 & 2.19 & 2.16 & 1.99 & 2.05 & $\underset{\pi}{\stackrel{0}{*}}$ & 1.96 \\
\hline Raw fat & 2.58 & 2.18 & 2.32 & 2.11 & 2.17 & 1.82 & 응 & 2.14 \\
\hline Raw fiber & 2.14 & 3.10 & 3.76 & 3.15 & 3.74 & 4.06 & $\frac{\bar{a}}{n}$ & 3.70 \\
\hline Carbohydrates & 73.52 & 76.74 & 77.45 & 80.29 & 82.30 & 82.12 & $\begin{array}{l} \pm \\
+ \\
4\end{array}$ & 83.80 \\
\hline Kcal & 211.8 & 225.5 & 211.6 & 216.9 & 209.4 & 199.7 & $\frac{t}{\sigma}$ & 206.1 \\
\hline
\end{tabular}

${ }^{\star}$ The ratio corresponds to the corn flour: sardine protein proportion.

sardine protein without its physical and sensory characteristics being modified. Enhanced tortillas potentially would optimize children growth in populations where maize tortilla constitutes the main source of energy and protein and where children's growth is deficient. 
Gaceta Médica de México. 2018;154

Table 5. Sensory evaluation of the tortillas prepared with different corn flour: sardine protein ratios

\begin{tabular}{|c|c|c|c|c|c|c|c|c|}
\hline Parameter & $92.5: 7.5$ & $95.0: 5.0$ & $96.25: 3.75$ & $97.5: 2.5$ & $98.75: 1.25$ & $99.37: 0.63$ & & 100 \\
\hline Taste (0-3) & 0.81 & 0.76 & 1.21 & 1.76 & 2.16 & 2.54 & $\stackrel{\infty}{-}$ & 2.82 \\
\hline Color (0-3) & 1.52 & 1.47 & 1.93 & 1.88 & 2.12 & 2.85 & N & 2.82 \\
\hline Odor (0-3) & 0.71 & 1.00 & 0.93 & 1.71 & 1.82 & 2.54 & $\gtrsim$ & 2.76 \\
\hline Softness (0-5) & 3.83 & 3.76 & 4.68 & 4.09 & 4.34 & 4.96 & $\frac{\text { ह }}{4}$ & 4.59 \\
\hline Smoothness (1-2) & 1.19 & 1.06 & 1.79 & 1.88 & 1.94 & 2.00 & (a) & 2.00 \\
\hline Puffing (0-2) & 1.00 & 1.00 & 2.00 & 2.00 & 2.00 & 2.00 & & 2.00 \\
\hline Folding (0-2) & 1.19 & 1.29 & 1.71 & 1.35 & 1.76 & 1.69 & $\frac{\bar{d}}{n}$ & 1.76 \\
\hline Total score & 10.25 & 10.34 & 14.25 & 14.67 & 16.14 & 18.58 & $\frac{\overline{0}}{3}$ & 18.75 \\
\hline
\end{tabular}

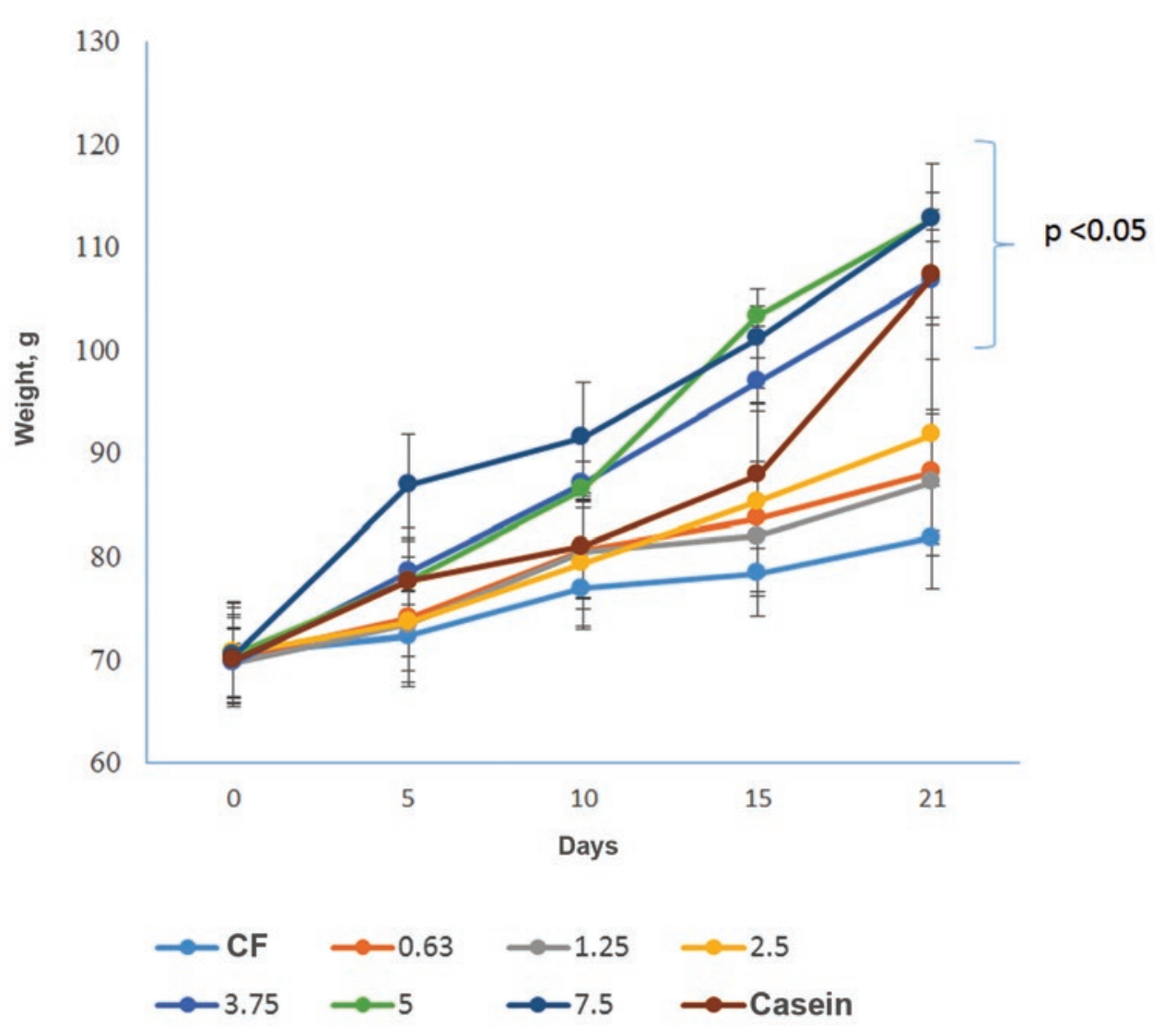

Figure 3. Growth curves of rats fed tortillas prepared with corn flour not supplemented or supplemented with different concentrations of sardine protein during the 21 days of experimentation. Eight groups of 6 rats fed on non-supplemented corn flour (CF), casein or sardine protein different concentrations were formed (two-way ANOVA).

The results are comparable with those in other studies that have demonstrated that the quality of corn tortillas improves when supplemented with legumes, both with whole-grain flour and with protein extract. However, the PER reported in legume-supplemented diets is approximately $1.8^{; 2,23}$ this is important because, although there isn't a PER value of best quality, it is suggested for it to be at least similar to the casein PER of 2.5, regarded as the reference value. ${ }^{23}$
The PER obtained in our study for the tortillas with a protein concentrate of $3.75 \%$ was 2.44 , suggesting that the use of a sardine protein concentrate is a better alternative than the use of legumes.

We recognize that other biological tests, such digestibility of the diets, were not performed in our study; however, the results observed in the rats' growth suggest that protein bioavailability of the different diets was adequate, since a direct association is observed 
Table 6. Biological tests in the blends with the best physical and sensory ratings in comparison with non-supplemented and casein-supplemented tortillas

\begin{tabular}{lcc}
\hline CF: SP blend & Experimental PER & Adjusted PER ${ }^{*}$ \\
\hline $96.25: 3.75$ & 2.17 & 2.44 \\
$97.5: 2.5$ & 1.47 & 1.66 \\
$98.75: 1.25$ & 1.51 & 1.70 \\
$99.37: 0.63$ & 1.35 & 1.52 \\
$100(N T)$ & 1.25 & 1.41 \\
Casein & 2.22 & 2.50 \\
\hline
\end{tabular}

CF: SP = corn flour: sardine protein. PER = protein efficiency ratio.

${ }^{*}$ Adjusted to casein PER of 2.50 .

between the amount of added protein and rats' growth. In other words, the higher the protein concentration in the tortillas, the more the growth of the rats in a dose-response fashion (Fig. 3).

We also recognize that this study is in a preliminary stage prior to proposing corn flour routine supplementation with sardine protein. It is indispensable for a study to be carried out in a model of human beings in order to demonstrate that sardine protein addition to corn tortillas really has an impact on children growth. Furthermore, it will be necessary for cost-effectiveness studies to be carried out in order to calculate the cost of supplemented tortillas as related to children growth improvement and the implications of this. For example, if better growth is reflected on lower rates if infection, hospitalization, medical treatment, etcetera.

Finally, we consider that this result is relevant from the point of view of public health because it proposes an alternative to improve the diet and, consequently, the nutritional status of populations with nutritional deficits, particularly in places with high rates of undernourishment and fish consumption is common, in order to improve the acceptance of foods.

\section{Acknowledgements}

We thank Mrs. Carmen Tavira Mojica, who facilitated the space and equipment for the preparation of the tortillas.

\section{Funding}

The project was funded with FIS/IMSS/PROT/ G12/1155 support granted by Fondo de Investigación en Salud of the Instituto Mexicano del Seguro Social.

\section{References}

1. Dirección General de Epidemiología. Encuesta Nacional de Nutrición 1988. Secretaría de Salud; México, 1988.

2. Rivera-Dommarco J, Shamah-Levy T, Villalpando-Hernández S, GonzálezDe-Cossío T, Hernández-Prado B, Sepúlveda J. Encuesta Nacional de Nutrición 1999. Estado nutricio de niños y mujeres en México. México: Instituto Nacional de Salud Pública, 2001.

3. Shamah-Levy T, Villalpando-Hernández S, Rivera-Dommarco JA. Resultados de nutrición de la ENSANUT 2007. México: Instituto Nacional de Salud Pública; 2006

4. GutiérrezJP, Rivera-DommarcoJ, Shamah-Levy T, Villalpando-HernándezS, Franco A, Cuevas-Nasu I, et al. Encuesta Nacional de Salud y Nutrición 2012. Resultados nacionales. México: Instituto Nacional de Salud Pública; 2012.

5. Shamah-Levy T, Cuevas-Nasu I, Rivera-Dommarco J, Hernández-Ávila M. Encuesta Nacional de Salud y Nutrición de Medio Camino 2016. Informe final de resultados. México: Instituto Nacional de Salud Pública; 2016.

6. Roche AF, Sun SS. Human growth: Assessment and interpretation. UK: Cambridge University Press; 2003.

7. Fuller MF. Protein and amino acid requirements. En: Stipanuk $M H$, Caudill MA, editores. Biochemical and physiological aspects of human nutrition. EE. UU.: Saunders; 2000.

8. Millward DJ, Jackson AA. Protein/energy ratios of current diets in developed and developing countries compared with safe protein/energy ratio: implications for recommended protein and amino acid intakes. Public Health Nutr. 2004;7:387-405.

9. Chávez Villasana A, Chávez MM. La tortilla de alto valor nutritivo. Evaluación de una harina enriquecida sobre la nutrición y la salud de dos comunidades rurales. México: McGraw-Hill Interamericana; 2004.

10. Bressani R, Elías LG, Scrimshaw NS, Guzmán MA. Nutritive value of Central American corns. VI. Varietal and environmental influence of nitrogen, essential amino acid and fat content of ten varieties. Cereal Chemistry. 1962;39:59-67.

11. Organización de las Naciones Unidas para la Agricultura y la Alimentación. El maíz en la nutrición humana. Italia: Organización de las Naciones Unidas para la Agricultura y la Alimentación; 1993.

12. Scrimshaw NS, Bressani R, Behar M, Viteri F. Supplementation of cereal proteins with amino acids. I. Effect of amino acid supplementation of corn masa at high levels of protein intake on the nitrogen retention of young children. J Nutr. 1958;66:485-499.

13. Bressani R, Scrimshaw NS, Behar M, Viteri F. Supplementation of cereal proteins with aminoacids. II. Effect of amino acid supplementation of corn masa at intermediate levels of protein intake on the nitrogen retention of young children. J Nutr 1958;55:501-513.

14. Truswell AS, Brock JF. Effects of amino acid supplements on the nutritive value of maize protein for human adults. Am J Clin Nutr. 1961;9: 715-718.

15. Sauberlich HE, Chang WY, Salmon WD. The comparative nutritive value of corn of high and low protein content for growth in the rat and chick. Jutr. 1953:51:623-635

16. Bressani R, Murillo B, Elías LG. Whole soybeans as a means of increasing protein and calories in maize based diets. J Food Sci. 1974;39:577.

17. Méndez-Bueno M, Vela-Gómez GA. Elaboración y evaluación sensorial, química y biológica de tortillas a base de maíz y algunas leguminosas comestibles. [Tesis de licenciatura]. México: Escuela de Ciencias Químicas, Universidad La Salle; 1996.

18. Pérez-Villaseñor J, Del-Valle FR, Salemme MM. Enriquecimiento de las tortillas con proteína de soya por medio de la nixtamalización de mezclas de maíz y frijol de soya. J Food Sci. 1974;39:244-248.

19. Brandsch C, Shukla A, Hirche F, Stangl GI, Eder K. Effect of protein from beef, pork, and turkey meat on plasma and liver lipids of rats compared with casein and soy protein. Nutrition. 2006;22:1162-1170.

20. Sure B. The addition of small amounts of defatted fish flour to whole yellow corn, whole wheat, whole and milled rye, grain sorghum and millet. I. Influence on growth and protein efficiency. II. Nutritive value of the minerals in fish flour. J Nutr. 1957:63:409-416.

21. Mosha TCE, Bennink MR. Protein quality of drum-processed cereal-bean-sardine composite supplementary foods for preschool-age children. J Sci Food Ag. 2004;84:1111-1118.

22. Sagarpa. [Sitio web]. La sardina. [Actualizado 2014 Sep 10] Disponible en: www.sagarpa.gob.mx/saladeprensa/infografias/Paginas/SardinaMexicana.aspx

23. AOAC. [Sitio web]. Official Methods of Analysis of AOAC International $20^{\text {th }}$ edition. Washington, EE. UU.: AOAC; 2016. 